\title{
FIRST RECORD OF THREE LARVALTREMATODES, RHIPIDOCOTYLE CAMPANULA, PHYLLODISTOMUM SP. AND ECHINOSTOMA SP. (DIGE- NEA: BUCEPHALIDAE, GORGODERIDAE AND ECHINOSTOMATIDAE) INFECTING FRESHWATER MUSSEL NITIA TERETIUSCULA IN EGYPT
}

\author{
By \\ MONA F. FOL ${ }^{1}$ and REWAIDA A. H. ABDEL-GABER ${ }^{1,2^{*}}$ \\ Department of Zoology ${ }^{1}$, Faculty of Science, Cairo University, Cairo, Egypt and \\ Department of Zoology ${ }^{2}$, College of Science, King Saud University, Riyadh, Saudi \\ Arabia ( ${ }^{*}$ Correspondence: rewaida@sci.cu.edu.eg)
}

\begin{abstract}
Unionidae is the most diverse family of freshwater bivalves; however, infectious diseases of these molluscs have received little attention. A total of 200 freshwater mussels from five species were collected monthly during the period of February 2016 to August 2017 from Tura region in River Nile, Cairo, Egypt during the current investigation. The collected samples consisted of 50 Corbicula fluminea, 50 Caelatura aegyptiaca, 50 Nitia teretiuscula, 30 Mutela rostrata and 20 Chambardia rubens. Mussels were dissected and examined for detection of parasitic infection. Larval trematodes were recovered from mussel species $N$. teretiuscula with infection rate 2\% (4/200). Light and scanning electron microscopic examinations showed that the pre-patent invasions of trematode parasites belong to three families, Rhipidocotyle campanula (Bucephalidae), Phyllodistomum sp. (Gorgoderidae) and Echinostoma sp. (Echinostomatidae). Also, the histopathological effects associated with larval trematode infection were studied in different tissues of $N$. teretiuscula. No infection was demonstrated in the mantle and visceral mass. The present study indicated that freshwater mussels can serve as first and second intermediate hosts for trematodes. In addition, this is the first study to report cercarial emergence from freshwater bivalves in this geographic region.
\end{abstract}

Key words: Freshwater mussels, Nitia teretiuscula, Rhipidocotyle campanula, Phyllodistomum sp., Echinostoma sp., Histopathological examination

\section{Introduction}

Invertebrate species represent a great percentage of animal diversity; however, they attract extremely minor research effort relative to vertebrates (Ricciardi and Rasmussen, 1999). Among them freshwater molluscs is one of the most diverse and endangered animals with limited research specialists (Carella et al, 2016). The use of freshwater molluscs in the biomedical research and environmental sentinels has dramatically grown in recent decades, as they have been known to play significant roles in public and veterinary health. Freshwater molluscs need to be scientifically explored (Supian and Ikhwanuddin, 2002) and extensively understand their comparative pathology (USEPA, 1992). Order Unionoida is a widespread group of bivalve molluscs commonly known as "freshwater mussels" including six families (Lydeard et al, 2004). Unionidae is the largest family with approximately 677 species (McElwain and Bullard, 2014), represented as worldwide distributed bivalves residing small ditches, ponds, lakes, canals and rivers (Strayer et al, 2004) and often used as a mall test in the eco-toxicological studies (Torres et al, 2004). Unionids provide a habitat for various free-living and parasitic symbionts as trematodes (Piechocki and Dyduch-Falniowska, 1993). Trematodes are responsible for a variety of parasitic diseases, some of which are transmitted through fish and shellfish (Aldana et al, 2009; Marcus et al, 2012). Different developmental stages of trematode parasites may use bivalves as the first intermediate host (sporocyst, redial and cercarial stages) or as the second intermediate host (metacercarial stage), or the bivalve may be the only host for all stages of the life cycle (DuobinisGray et al, 1991).

Bucephalidae is one of the largest digenean families with 25 genera containing hun- 
dreds of described species characterized by having a muscular organ at the anterior end termed as "rhynchus" which is used to attach to their hosts (Muñoz and Bott, 2011). Bucephalus species are the most common parasites of commercial bivalves; the adult stage of the trematode life cycle is completed in different fish or bird species (Cribb et al, 2001). Also, genus Phyllodistomum is the only genus of family Gorgoderidae observed in freshwater unionids (Hoffman, 1999), but immature stages in this family are difficult to identify and have often been assigned only to the family Gorgoderidae (GeorgeNascimento et al, 1998). In addition, Echinostomatidae is a family of digenetic trematode worms (type genus Echinostoma) that are rare in man but common and widely distributed as parasites of invertebrate animals. Laruelle et al. (2002) only found an unidentified species of Echinostomatidae in zebra mussels from Europe. Few studies have specifically addressed the impact of larval trematodes on their hosts (Chai et al, 2008; Nguyen et al, 2009). Mussels parasitized by digenetic (host-castrating) trematodes exhibit decreased growth rates, physiological condition, larval production and tissue damage (Fisher et al, 2000; Gustafson et al, 2005a, b; Howard et al, 2004; Keiser and Utzinger 2009; Phan et al, 2010; Muñoz et al, 2013), so histopathological studies have been used as components for the examination of infected mussels (Chittick et al, 2001).

The aim of the present study was to perform a detailed morphological examination of the different larval stages infecting freshwater mussels using light and scanning electron microscopes. In addition, histopathological effects of the recorded parasites on their host tissues were studied.

\section{Materials and Methods}

Mussel samples collection: Adult mussels $(n=200)$ were monthly and randomly collected during the period of February 2016 to August 2017, from rocky muddy bottoms of Tura region (Helwan Governorate), and then transported immediately to Laboratory of Invertebrates at Zoology Department, Faculty of Science, Cairo University, Egypt. Mussels were held in small containers provided with well-aerated water and sediments, then sorted and maintained under the same conditions of food and temperature of its original environment. Identification of the freshwater mussels was performed according to Ibrahim et al. (1999) and Graf and Cummings (2007). The collected mussel specimens belonging to 3 families of 5 genera, 50 of each C. fluminea (Müller, 1774) (F: Cyrenidae), C. aegyptiaca (Cailliaud, 1827) (F: Unionidae), N. teretiuscula (Philippi, 1847) (F: Unionidae), 30 of $M$. rostrata (Rang, 1835) (F: Iridinidae) and 20 of C. rubens (Lamarck, 1819) (F: Iridinidae).

Parasitological investigation: Each mussel was dissected and examined for the presence of parasitic infections. Flushed parasites stages from the gills and reproductive tissue with saline solution were carefully isolated and preserved in $70 \%$ ethanol. Prevalence for parasite infections was statistically analyzed according to the guidelines stated by Bush et al. (1997). Morphology of the larval stages was studied on living and fixed specimens; neutral red and Nile blue stains were used for intra-vital staining. For morphological examination, fixed specimens were stained with acetocarmine, dehydrated in a graded ethanol series, cleared in clove oil, and then mounted permanently in Canada balsam. Photomicrographs were taken using Zeiss Axiovert 135 microscope supplied with a Canon Digital Camera. Measurements of larval stages are presented in micrometer; mean values are given in parentheses. Trematodes were identified based on the standard keys (Skrjabin et al, 1964; Yamaguti, 1971; Schell, 1985; Gibson and Bray, 2002; Campbell, 2008).

Scanning electron microscopic study: Recorded parasites were fixed in 3\% glutaraldehyde, then washed in sodium cacodylate buffer, dehydrated in a graded series of ethanol and infiltrated with amyl acetate. After 
passing through an ascending series of Genesolv D, they were processed in a critical point dryer "Bomer-900" with Freon 13, sputter-coated with gold-palladium in a Technics Hummer, and then examined and photographed under an Etec Autoscan at 20$\mathrm{kV}$ Jeol scanning electron microscope in Electron Microscope Unit in Faculty of Science, Ain shams University, Egypt.

Histological examinations: Infected tissues (mantle, gills, viscera and reproductive tissues) of studied mussels were fixed in Bouin's solution for $48 \mathrm{hrs}$. The fixed samples were washed in tap water overnight and exposed to ascending concentrations of ethyl alcohol $(70 \%, 80 \%, 90 \%$ and $100 \%)$, then cleared in xylene, infiltrated with liquid paraffin at $58{ }^{\circ} \mathrm{C}$, and finally embedded in paraffin blocks. The prepared blocks were trimmed and sectioned at 5-8 $\mu \mathrm{m}$ thick, then cut on a rotary microtome, stained with Harris' Hematoxylin and counter-stained with Eosin (H\&E stain) and then examined and photographed by a Zeiss Research Photomicroscope. Histological terminology for Unionidae follows McElwain and Bullard (2014).

Ethical Standards: All procedures contributing to this work comply with the ethical standards of the relevant national guides on the care and use of laboratory animals and have been approved and authorized by Institutional Animal Care and Use Committee (IACUC) in Faculty of Science, Cairo University, Egypt.

\section{Results}

Parasitological investigation indicated that out of 200 freshwater mussels $4(2 \%) N$. teretiuscula were infected (Figs. 1-5), while the other examined bivalves; $C$. fluminea, $C$. aegyptiaca, $M$. rostrata and $C$. rubens did not harbor any larval trematodes. Histological examination of soft parts of the infected mussels demonstrated larval trematodes in the gill lamellae, inter-lamellar connective tissues and spaces of the gills in addition to reproductive tissues for male and female bivalves. $N$. teretsicula showed equal infection for both sexes with ratio $1: 1$. The recovered larval trematodes were identified as sporocyst of Rhipidocotyle campanula (F: Bucephalidae), cercariae of Phyllodistomum sp. (F: Gorgoderidae), and metacercariae of Echinostomatids (F: Echinostomatidae).

Microscopic examinations of larval stages (Figs. 6-19):

1-Rhipidocotyle campanula (based on 20 live specimens): This larval stage appeared as ribbon of sporocysts with multi-branched constrictions or ramifications, dark in color and comprising a great number of cercariae at different stages of development. These sporocysts measured $0.520-1.620(0.849 \mu \mathrm{m})$ long and $0.300-0.870(0.529 \mu \mathrm{m})$ wide. This stage lacks suckers and having instead a muscular organ called a "rhynchus" at the front end which is used for attachment to host tissues.

2- Cercaria of Phyllodistomum sp. (based on 20 specimens from permanent mounts): The body was dorso-ventrally flattened with slightly narrower anterior end and broader posterior end. Body measured 0.395-0.860 $(0.593 \mu \mathrm{m})$ long with maximum width at the level of the anterior testis reached about $0.123-0.250(0.173 \mu \mathrm{m})$. Mouth sub-terminally. Oral sucker was sub-terminal and measured 0.063-0.143 $(0.096 \mu \mathrm{m})$ long and 0.063-0.108 $(0.084 \mu \mathrm{m})$ wide. Ventral sucker rounded, measured $0.060-0.145(0.104 \mu \mathrm{m})$ long and $0.070-0.138(0.102 \mu \mathrm{m})$ wide and located at $0.175-0.500(0.325 \mu \mathrm{m})$ from the anterior end. Tegument was thin with very fine papillae distributed irregularly from the anterior to posterior end of the body and condensed at the posterior part of the body. Spines were not observed.

3- Metacercaria of Echinostoma sp. (based on 20 specimens from permanent mounts): This stage was folded within a transparent cyst, spherical in shape with double walled, and enclosed in a thin sheet of connective tissue of the host. Also, excretory granules were detected. The mean diameter was within the range of $120-165(157 \mu \mathrm{m})$.

Histopathological examination (Figs. 20-37) 
revealed different developmental stages in the gills and reproductive tissues of $N$. teretiuscula but was not perceived in the mantle and digestive gland. Also, inflammation of the connective tissue was observed and lesions appeared as either diffuse hemolytic infiltration of the vesicular connective tissue or as discrete focal accumulations that displaced connective tissues and organ systems associated with the infestation by larval trematodes. Moreover, in the gill tissues a large number of cysts were detected with highly accumulated numbers of hemocytes around the infection sites, indicating activation of the mussel defensive mechanisms. All examined mussels showed severe inflammation accompanied by an increased prevalence of granulocytomas (either as single or multiple lesions) within the interconnective tissues of the gill lamellae. Furthermore, larval stages may penetrate into the reproductive tissues of male and female mussels and producing disorders of the gametes.

\section{Discussion}

Studies on mollusc-transmitted diseases are very important for veterinary and public health (Krailas et al, 2008). Aquatic molluscs have been reported as the first and second intermediate hosts of trematodes and various studies have been conducted on molluscan fauna and their trematode infections (Grizzle and Brunner, 2009; Chantima et al, 2013). Unionids are important factors in the functioning of the freshwater ecosystems (Vaughn and Hakenkamp, 2001). They constitute a significant benthos biomass (Piechocki, 1999) and filter large volumes of water (Strayer et al, 2004), thus contributing to the purification of the aquatic systems (Pusch et $a l, 2001)$. They represented a good source of food for other organisms (Zahner-Meike and Hanson, 2001) and also provided a habitat for various free-living and parasitic symbionts (Piechocki and Dyduch-Falniowska, 1993).

In the present study, the only unionid species found infected by larval trematodes was
$N$. teretusicula (2\%), while other freshwater bivalves did not harbor any larval trematodes. This result demonstrates that male and female $N$. teretusicula showed equal infection with ratio $1: 1$ which agreed with the findings of Waffle (1967) who suggested that neither size nor sex of the host apparently have effect on infectivity by these parasites. These results contradicted with Taskinen and Valtonen (1995), followed by Heino and Kaitala (1996), they observed an increase in the prevalence of parasites in older mussels and higher infection rates in females. Also, Müller et al, (2015) recorded higher infection rates in older female mussels, D. polymorpha with $R$. campanula and Phyllodistomum sp. Previous studies by Stadnychenko (1974), Yanovich and Stadnychenko (1997), Chernomaz (2001), Laruelle et al. (2002) and Grizzle and Brunner (2009) suggested that B. polymorphus was specific to Dreissenidae not Unionidae, and the earlier data on its presence in unionids should be verified due to the high degree of similarity between the larval stages of $B$. polymorphus and $R$. campanula (Karatayev et al, 2000). Bucephalid trematodes in unionids belong to the genus Rhipidocotyle, now named B. polymorphus (Kelly, 1899; Yanovich and Stadnichenko, 1997). In the line of this expectation, B. polymorphus which is a synonym of $R$. campanula was also specific to Unionidae, this agreed with Baturo (1977) who found sporocysts of $R$. campanula in the painter's mussel Unio pictorum and provided detail description of the developmental stages of this parasite. This also agreed with our findings that record sporocysts of $R$. campanula in the unionid, $N$. teretusicula. Laruelle et al. (2002) reported sporocysts of $B$. polymorphus in the connective-tissue spaces, i.e. gonadal tissues, and gills. Also, Pina et al. (2009) observed cercaria of $B$. minimus infecting the digestive gland and gonads of its first intermediate host, the edible cockle Cerasto dermaedule. Also, Marchiori et al. (2010) demonstrated sporocysts and cercariae of B. marg- 
aritae in the mantle, digestive gland and gonad of the brown mussel Pernaperna. Additionally, the findings stated by Müller et al, (2015) recorded trematode larvae in the gonads more than in hepato-pancreas of the duck mussels. These results agreed with our observations of the larval stages of bucephalid but with some respect to the mantle epithelium, the digestive gland and other visceral organs.

Also, in the present study, larval stages of Phyllodistomum sp. were detected in the gills and reproductive tissues of $N$. teretusicula belonging to family Unionidae. This result agreed with Thomas (1956) who reported that European gorgoderian Phyllodistomum simile is found in the urinary bladder of brown trout as an adult, and sporocysts are found in the epi-branchial cavity between the gill lamellae of Sphaerium corneum. Also, Waffle (1967) found cercariae of Phyllodistomum staffordi infecting gills of the fingernail clam Sphaerium lacustre, followed by the finding of Taskinen et al. (1997) who reported that the gonads of the duck mussels in two Finnish lakes were more heavily parasitized by $R$. campanula and $R$. fennica than any other organs. Additionally, Rantanen et al, (1998) recorded that the sphaeriid clam Pisidium amnicum was infested by larval Phyllodistomum elongatum which caused castration of the host and Shiver (2002) recorded that Rhipidocotyle sp. were found infecting the gonadal tissues of the freshwater clam Lampsilis Rafines queana. Moreover, Kudlai and Yanovich (2013) detected larval stages of Phyllodistomum sp. in bivalves of the families Unionidae and Sphaeriidae. Finally, Taskinen $e t$ al. (1997; 2016) reported that the ribbons of sporocyst of $R$. campanula and $R$. fennica were present in the gonadal tissues of the freshwater clam Anodonta piscinalis.

Various species of freshwater snails have been reported to play a dual role of the first and second intermediate hosts of echinostomes in Thailand, namely, Indoplanorbis spp., Gyraulus spp., Lymnaea spp., Pila spp., Viviparus spp., Filopaludina spp. and Bithynia spp. as recorded by Chantima et al, (2013). Also, Chantima et al, (2013) first reported metacercariae of $E$. revolutum in the snail host, $C$. helena and Zimmermann et al, (2015) observed larval stages of Echinostoma spp. parasitize gastropods as both first and second intermediate hosts. These data reversed our findings that record metacercariae of echinostome infecting the gills of unionid freshwater mussel, $N$. teretusicula which was considered as second intermediate host. However, it agreed with results of Molloy et al, (1997) who reported that zebra mussels are often second intermediate hosts to trematodes in the family Echinostomatidae. Also, Kanev et al. (1998) reported metacercariae of Echinostoma sp. infected pulmonate and Semenas et al, (1999) found metacercariae of Echinostomatidae infecting viscera and gonads of Diplodon chilensis. Also, Han et al, (2009) discovered metacercariae of Himasthla alincia (Echinostomatidae) in brackish water bivalves in the Republic of Korea. Lastly, Bakhmet et al. (2017) showed that metacercariae of echinostomatidae disrupt neuronal control of cardiac function and lower growth rate in the blue mussels Mytilus edulis in situ. Besides, Han et al. (2009) and Chantima et al. (2013) described metacercariae of echinostomatidae folded within a transparent cyst with a bilayered wall, spherical in shape and reached $136.0-195.0 \mu \mathrm{m}$ in diameter. Cyst wall consisted of outer transparent layer and inner opaque layer, collar spines (37 in total number), were presented in both fresh and fixed specimens. The excretory granules and suckers were visible, these results agreed with the present description of metacercariae of echinostomes but with the respect to the diameter the present results ranged from 120$165(157 \mu \mathrm{m})$.

The present investigation recorded localized (focal) tissue damage associated with larval trematodes in the histological sections of gills and reproductive tissues. Previous studies regarding parasitic infections in mus- 
sels have provided little specificity regarding how these infections affect tissue (Vidrine, 1996; Wu et al, 2008). In addition, histopathological studies showed that gills were the most infected organ which contradicts with the study of Lajtner et al. (2008) that confirmed gonads of $D$. polymorpha were predominantly attacked by $B$. polymorphus infection more than any other organ. Also, Kudlai and Yanovich (2013) found larval stages of Phyllodistomum sp. in the gonads of the duck mussel A. anatina. Conversely, the present results agreed with their findings where digestive gland of the majority of infected mussels was not affected by trematode infection. Similar results were reported by Molloy et al. (1996) and Laruelle et al. (2002) as well as present results.

The most serious effect of bucephalidis is host sterility with gonadal tissues replaced by sporocysts also accompanied to follicle fibrosis. Additional lesions were also recorded by other studies (Kniskern, 1952; Yanovich and Stadnichenko, 1997). The present histopathological study showed follicle fibrosis and lesions in the connective tissues of the different gill parts and reproductive tissues in N. teretusicula. Also, an outer eosinophilic membrane was sometimes observed around larval stages in the gill, and around the integument of the reproductive tissue. However, this membrane was not always apparent, especially when larval stages were located in fibrous tissues such as interbranchial septum. A single layer of flattened hemocytes, eosinophilic cytoplasm and a small protruding nucleus were most evident in subcutaneous tissues of the reproductive tissue. An outer layer of hemocytes may either represent a limited host response or hemocytes that have become flattened. Previous studies by Humes and Jamnback (1950), Humes and Russell (1951), Humes and Harris (1952) indicated that $N$. ingens might limit mussel populations by obstructing water tubes of marsupia. Besides, Mitchell (1955) reported hyperplasia, followed by Flook and Ubelaker (1972) who reported hypertrophy of tissues infected with larval stages.

\section{Conclusion}

The current investigation may represent the first comprehensive series of bucephalid, gorgoderid and echinostomatid larval stages in addition to its pathological effects in the tissues of freshwater mussel $N$. teretusicula. Also, future studies should focus on the search for new trematode species, using: (i) various regions along the River Nile, (ii) many native and alien bivalve species, and (iii) different research methods, including morphological and molecular diagnosis of trematode species. The research should also contribute to answer the question of the environmental determinants of differences between the infection of Unionidae and Dreissenidae residing on their shells.

\section{Acknowledgments}

The authors are thankful to Faculty of Science, Cairo University, Cairo, Egypt, for kind providing all facilities to complete this work. Thanks are also extended to Prof. Dr. Manal F. El Garhy for kind revising this manuscript.

Conflict of interest: The authors have indicated that they have no conflict of interest regarding the content of this article.

\section{References}

Aldana, M, González, K, Loot, G, Pulgar, J, Marquet, P, 2009: First intermediate host of the digenean trematode Proctoeces lintoni (Fellodistomidae) in Chile. J. Parasitol. 95: 1408-14

Bakhmet, PI, Nikolaev, K, Levakin, I, 2017: Effect of infection with Metacercariae of $\mathrm{Hi}$ masthla elongata (Trematoda: Echinostomatidae) on cardiac activity and growth rate in blue mussels (Mytilus edulis) in situ. J. Sea Res. 123: 51-4

Baturo, B, 1977: Bucephalus polymorphus Baer, 1827 and Rhipidocotyle illense Ziegler, 1883 (Trematoda, Bucephalidae): morphology and biology of developmental stages. Acta Parasitol. Polonica 24: 203-20

Bush, AO, Lafferty, KD, Lotz, JM, Shostak, AW, 1997: Parasitology meets Ecology on its own terms: Margolis et al. revisited. J. Parasit. 83:575-83.

Campbell, RA, 2008: Family Gorgoderidae Lo- 
ss,1899: Keys to the Trematoda. V. 3; Eds, RA, Bray, DI, Gibson, A. Jones. Wallingford: CABI Publishing and the Natural History Museum, London.

Carella, F, Villari, G, Maio, N, DeVico, G, 2016: Disease and Disorders of Freshwater Unionid Mussels: A Brief Overview of Recent Studies Frontiers in Physiology 7:489-7

Chai, TTK, Dalsgaard, A, Turnbull, JF, Tuan, PA, Murrell, KD, 2008: Prevalence of zoonotic trematodes in fish from a Vietnamese fish-farming community. J. Parasit. 94:423-8

Chantima, K, Chai, J, Wongsawad, C, 2013: Echinostoma revolutum: Freshwater Snails as the Second Intermediate Hosts in Chiang Mai, Thailand. Korean J. Parasit. 51, 2:183-9

Chernomaz, TV, 2001: Ciliary activity of cells of gill and leg glimmeral epithelium of Unionidae invaded by trematodes of Aspidogaster conchicola and Bucephalus polymorphus. Parazitol. 35:443-8

Chittick, B, Stoskopf, M, Law, M, Overstreet, R, Levine, J, 2001: Evaluation of potential health risks to eastern elliptio (Elliptio complanata) (Mollusca: Bivalvia: Unionida: Unionidae) and implications for sympatric endangered freshwater mussel species. J. Aquat. Ecosyst. Stress Recovery 9:35-42

Cribb, TH, Bray, RA, Littlewood, DTJ, 2001: The nature and evolution of the association among digeneans, mollusks, and fishes. Int. J. Parasit. 31:997-1011

Duobinis-Gray, LF, Urban, EA, Sickel, JB, Owen, DA, Maddox, WE, 1991: Aspidogastrid (Trematoda) parasites of unionid (Bivalvia) molluscs in Kentucky Lake. J. Helminthol. Soc. Wash. 58:167-70

Fisher, GR, Dimock, RV, Kuhn, RE, 2000: The symbiotic water mite Unionicolaformosa (Acari: Unionicolidae) ingests mucus and tissue of its molluscan host. J. Parasit. 86:1254-8

Flook, JM, Ubelaker, JE, 1972: A survey of metazoan parasites in unionid bivalves of GarzaLittle Elm Reservoir, Denton County, Texas. Texas J. Sci. 23:381-92

George-Nascimento, M, Balboa, L, Aldana, M, Olmos, V, 1998: Las lapas Fissurella spp. (Mollusca: Archaeogastropoda) y el pejesapo $\mathrm{Si}$ cyases sanguineus (Pisces: Gobiesocidae) son ho-spedadores secuencialesde Proctoeces linto$n i$ (Digenea: Fellodistomidae) en Chile. Rev. Chil. Hist. Natural 71:169-76.

Gibson, DI, Bray, AR, 2002: Keys to the Trem- atoda. Vol.1. CABI Publishing and The Natural History Museum, London.

Graf, DL, Cummings, KS, 2007: Review of the systematics and global diversity of freshwater mussel species (Bivalvia: Unionoida). J. Mollus. Stud. 73:291-314

Grizzle, JM, Brunner, CJ, 2009: Infectious diseases of freshwater mussels and other freshwater bivalve mollusks. Rev. Fisher. Sci. 17: 425-67

Gustafson, LL, Stoskopf, MK, Bogan, AE, Showers, W, Kwak, TJ, et al, 2005a: Evaluation of a nonlethal technique for hemolymph collection in Elliptio complanata, a freshwater bivalve (Mollusca: Unionidae). Dis. Aquat. Org. 65:159-65

Gustafson, LL, Stoskopf, MK, Showers, W, Cope, G, Eads, C, et al, 2005b: Reference ranges for hemolymph chemistries from Elliptio complanata of North Carolina. Dis. Aquat. Org. 65:167-76

Han, ET, Whang, JD, Chai, J Y, 2009: Himasthla alincia (Echinostomatidae): metacercariae in brackish water bivalves and their growth and development in experimental animals. J. Parasit. 95, 6: 1415-20

Heino, M, Kaitala V, 1996: Optimal resource allocation between growth and reproduction in clams: why does indeterminate growth exist? Funct. Ecol. 10:245-51

Hoffman, GL, 1999: Parasites of North American freshwater fishes, $2^{\text {nd }}$ ed. Ithaca, NY: Comstock Publishing Associates.

Howard, DW, Lewis, E.J, Keller, BJ, Smith, CS, 2004: Histological techniques for marine bivalve mollusks and crustaceans. NOAA Tech. Memorandum NOS NCCOS 5

Humes, AG, Harris, SK, 1952: The clam hosts of Najadi colaingens (K.) Acarina in a Quebec Lake. Canad. Field-Naturalist 66:83-4

Humes, AG, Jamnback, HA, 1950: Najadi colaingens (Koenike), a water-mite parasitic in freshwater clams. Psyche 57:77-87

Humes, AG, Russell, HD, 1951: Seasonal distribution of Najadi colaingens (Koenike) (Acarina) in a New Hampshire pond. Psyche 58:111-9 Ibrahim, AM, Bishai, HM, Khalil, MT, 1999: Freshwater Molluscs of Egypt. Department of Nature Protection, Egyptian Environmental Affairs Agency, Cairo, Egypt

Kanev, I, Sorensen, R, Sterner, M, Cole, R, Fried, B, 1998: The identification and characteristics of Echioparyphium rubrum (Cort, 1914) 
comb. new (Trematoda, Echinostomatidae) based on experimental evidence of the life cycle. Acta Parasitol. 43:181-8

Karatayev, AY, Burlakova, LE, Molloy, DP, Volkova, LK, 2000: Endosymbionts of Dreissena polymorpha (Pallas) in Belarus. Internat. Rev. Hydrobiol. 85:543-59

Keiser, J, Utzinger, J, 2009: Food-borne trematodiasis. Clin. Microbiol. Rev. 22:466-83

Kelly, HM, 1899: A statistical study of the parasites of the Unionidae. Bull. Ill. State Lab. Nat. Hist. 5:399-418

Kniskern, VB, 1952: Studies on the trematode family Bucephalidae Poche, 1907, Part II: The life history of Rhipidocotyle septpapillata Krull, 1934. Trans. Am. Microsc. Soc. 71:317-40

Krailas, D, Chotesaengsri, S, Pattaradussadee, N, Notesiri, N, Dechruksa, W, 2008: Bucephalid (Gasterostome) cercariae obtained from freshwater clams in Thailand. J. Trop. Med. Parasitol. 31:70-6

Kudlai, OS, Yanovich, LN, 2013: Larval stages of Phyllodistomum sp. (Digenea, Gorgoderidae) from the duck mussels Anodonta anatina in Ukraine. UDc 595. 122: 594-5

Lajtner, J, Luciæ, A, Marušiæ, M, Erben, R, 2008: The effects of the trematode Bucephalus polymorphus on the reproductive cycle of the zebra mussel Dreissena polymorpha in the Drava River. Acta Parasitol. 53, 1:85-92

Laruelle, F, Molloy, DP, Roitman, A, 2002: Histological analysis of trematodes in Dreissena polymorpha: their location, pathogenicity, and distinguishing morphological characteristics. J. Parasit. 88:856-63

Lydeard, CR, Cowie, H, Ponder, WT, Bogan, AE, Bouchet, P, et al, 2004: The global decline of non-marine mollusks. Biosci. 54:321-30

Marchiori, N, Magalhães, M, Rachel, A, Pereira, J, 2010: The life cycle of Bucephalus margaritae Ozaki and Ishibashi, 1934 (Digenea, Bucephalidae) from the coast of Santa Catarina State, Brazil. Acta Scientiarum Biol. Sci. 32, 1: 71-8

Marcus, S, Maqbool, A, Khan, N, Iqbal, KJ, Ashraf, K, Ahmad, N, 2012: Food borne parasitic zoonosis with special reference to metacercarial infection in fishes. J. Anim. Plant Sci. 22, 3:619-21

McElwain, A, Bullard, SA, 2014: Histological atlas of freshwater mussels (Bivalvia, Unionidae) Villosa nebulosa (Ambleminae: Lampsilini), Fusconaia cerina (Ambleminae: Pleurobe- mini) and Strophitus connasaugaensis (Unioninae: Anodontini). Malacol. 57: 99-239

Mitchell, RD, 1955: Anatomy, life history, and evolution of the mites parasitizing freshwater mussels. Miscellaneous Publications Museum of Zoology, University of Michigan No. 89

Molloy, DP, Karatayev, AY, Burlakova, LE, Kurandina, DP, Laruelle, F, 1997: Natural enemies of zebra mussels: Predators, parasites, and ecological competitors. Rev. Fisher. Sci. 5:27-97 Molloy, DP, Roitman, VA, Shields, JD, 1996: Survey of the parasites of zebra mussels (Bivalvia: Dreissenidae) in north western Russia, with comments on records of parasitism in Europe and North America. J. Helminthol. Soc. Washing. 63:251-6

Müller, T, Czarnoleski, M, Labecka, AM, Cichy, A, Zaja, K, et al, 2015: Factors affecting trematode infection rates in freshwater mussels. Hydrobiologia 742:59-70

Muñoz, G, Bott, N, 2011: A new species of Prosorhynchoides (Trematoda, Bucephalidae) from the intertidal rocky zone of central Chile. Acta Parasitologica 56:140-6

Muñoz, G, López, Z, Cárdenas, L, 2013: Morphological and molecular analyses of larval trematodes in the intertidal bivalve Perumytiluspurpuratus from central Chile. J. Helminthol. 87, 3:356-63

Nguyen, TLA, Nguyen, TP, Johansen, MV, Murrell, KD, Phan, TV, Dalsgaard, A, 2009: Prevalence and risks for fish borne zoonotic trematode infections in domestic animals in a highly endemic area of North Vietnam. Acta. Trop. 112:198-203

Phan, VT, Ersboll, KA, Nguyen, VK, Madsen, H, Dalsgaard, A, 2010: Farm-level risk factors for fish-borne zoonotic trematode infection in integrated small-scale fish farms in North Vietnam. PLoS Negl. Trop. Dis. 4:e742

Piechocki, A, 1999: Reproductive biology of Unio pictorum (Linnaeus) and U. tumidus Philipsson in the Pilica River (Central Poland). Heldia 4:53-60

Piechocki, A, Dyduch-Falniowska, A, 1993: Mięczaki (Mollusca)-Małże (Bivalvia). Fauna Słodkowodna Polski, Wydawnictwo Naukowe PWN, Warszawa

Pina, S, Barandela, T, Joaõ Santos, M, Russell-Pinto, F, Rodrigues, P, 2009: Identification and description of Bucephalus minimus (Digenea: Bucephalidae) life cycle in Portugal: Morphological, histopathological and molecular data. 
J. Parasit. 95, 2:353-9

Pusch, MJ, Siefert, J, Walz, N, 2001: Filtration and respiration rates of two unionid species and their impact on the water quality of a low land river. In: Bauer F., Wachtler K. (eds). Ecology and Evolution of the Freshwater Mussels Unionoida. Springer-Verlag, Heidelberg, Germany Rantanen, JT, Valtonen, ET, Holopainen, IJ, 1998: Digenean parasites of the bivalve mollusk Pisidium amnicum in a small river in eastern Finland. Dis. Aquat. Org. 33:201-8

Ricciardi, A, Rasmussen, JB, 1999: Extinction rates of North American freshwater fauna. Conservation Biol. 13:1220-2

Schell, S, 1985: Handbook of Trematodes of North America, North of Mexico. University Press of Idaho, Moscow, USA.

Semenas, L, Brugni, N, Ostrowski de Nunez, M, 1999: Metacercariae of Echinostomatidae in Diplodon chilensis (Unionacea: Pelecypoda) and description of Echinoparyphum megacirrus sp, in Patagonia (Argentina). Acta Parasitol. 44, 1: 63-7

Skrjabin, KI, Koval, VP, Gushanskaya, LH, 1964: Keys to the Trematodes Animals and Man. University of Illinois Press, Urbana. USA

Stadnychenko, AP, 1974: The infection of Uniopictorum and Anodonta piscinalis (Mollusca: Lammellibranchia) with parthenites of Bucephalus polymorphus trematodes and the effect of the parasites of the host organism. Parazitol. 8:420-5 Strayer, DL, Downing, JA, Haag, WR, King, TL, Layzer, JB, et al, 2004: Changing perspectives on pearly mussels, North America's most imperiled animals. Biosci. 54:429-39

Supian, Z, Ikhwanuddin, AM, 2002: Population dynamics of freshwater molluscs (Gastropod: Melanoides tuberculata) in Crocker Range Park, Sabah. ASEAN Review of Biodiversity and Environmental Conservation (ARBEC)

Taskinen, J, Mäkelä, T, Valtonen, ET, 1997: Exploitation of Anodonta piscinalis (Bivalvia) by trematodes: Parasite tactics \& host longevity. Ann. Zool. Fennici, 34:37-46
Taskinen, J, Valtonen, ET, 1995: Age, size, and sex specific infection of Anodonta piscinalis (Bivalvia: Unionidae) with Rhipidocotyle fennica (Digenea: Bucephalidae) and its influence on host reproduction. Canad. J. Zool. 73:887-97

Thomas, JD, 1956: Life history of Phyllodistomum simile Nybelin. Nature (London), 178: 1004

Torres, P, Villalobos, L, Woelfl, S, Puga, S, 2004: Identification of the copepod intermediate host of the introduced broad fish tapeworm, $D i$ phyllobothrium latum, in southern Chile. J. Parasit. 90:1190-3

USEPA 1992: Framework for Ecological Risk Assessment (EPA/630/R-92-001). U.S. Washington, DC: Environmental Protection Agency, Risk Assessment Forum

Vaughn, CC, Hakenkamp, CC, 2001: The functional role of burrowing bivalves in freshwater ecosystems. Freshwater Biol. 46:1431-46

Vidrine, MF, 1996: North American Najadicola and Unionicola: Collections and communities. Eunice, LA: Gail Q. Vidrine Collectables

Wu, H, Xie, Y, Wen, C, Feng, T, 2008: Histopathological effect of Unionicola arcuata eggs on different tissues in Cristaria plicata. Jiangxi Sci. 26:544-7

Yamaguti, S, 1971: Synopsis of the Digenetic Trematodes of Vertebrates. Tokyo: Keigaku Publishing Company

Yanovich, LN, Stadnychenko, AP, 1997: Molluscs of the family Unionidae from the Central Polessye as intermediate hosts of the trematodes. Parazitol. 31:314-20

Zahner-Meike, E, Hanson, JM, 2001: Effect of muskrat predation on naiads. In: Ecology and Evolution of the Freshwater Mussels Unionoida. Bauer F, Wachtler K. (eds.). Springer-Verlag, Heidelberg, Germany

Zimmermann, M R, Kyle, E L, Gerald, WE, 2015: Auto-infection by Echinostoma spp. cercariae in Helisoma anceps. Acta Parasitol. 60, 4: 700-6.

\section{Explanation of figures}

Figs. 1-5: Micrographs of freshwater mussel N. teretiuscula; 1 External view (EV) of shell with anterior (AS) and posterior (PS) ends and oldest part of shell (umbo) (U). 2-5: Inner view (IV) of shell; 2 Soft parts of uninfected shell with gills (G), viscera (V), foot (F), and mantle (M). 3: Swollen brood gills of uninfected shell with its eggs. 4, 5: Infected mussel with white knot on gills.

Figs. 6-12 Photomicrographs of three larval stages infecting $N$. teretiuscula; 6-8 Metacercariae of Echinostomatids with outer membrane (OM), inner membrane (IM), excretory granules (EG), and cercariae (C); 100×, 400×. 9, 10 Cercariae of Phyllostomium sp. with oral sucker (OS) and ventral sucker (VS); 100×. 11, 12: Ribbon sporocysts of Rhipidocotyle campanula inside cyst (CW) (11) and outside cyst (12) with ramifications (RA); 100×.Figs. 13-19: Scanning electron micrographs of larval trematodes stages infecting N. teretiuscula; 13-15: Metacercariae (MC) of Echinostomatids. 16, 17: Cercariae of Phyllodistomum sp. with oral sucker (OS) and ventral sucker (VS). 18, 19: Ribbon sporocyst of $R$. campanula with ramifications (RA) and rynchus (R).

Figs. 20-21: Photomicrographs of gills of N. teretiuscula; 20: Uninfected gills with gill filaments (GF) and gill lamellae (L); 10×. 21: Infected gills with entanglement knot (EK) of ribbon sporocysts of $R$. campanula; 10×. 
Figs. 22-28: Photomicrographs of histological sections; 22: Uninfected gills of N. teretiuscula with water tubes (WT), and gill lamellae (L) separated from each other by interlamaller spaces (ILS); 100×. 23 Non-infected gills showing larvae (La) of N. teretiuscula; 100×. 24-28 Infected gills of $N$. teretiuscula showing: 24, 25 Ribbon sporocyst (SP) of $R$. campanula. 26 Metacercariae (MC) of Echinostomatids and cercaria (C) of Phyllodistomum sp.; 400×. 27, 28 Cercaria(C) of Phyllodistomum sp. with oral sucker (OS) and ventral sucker (VS); 400×.

Figs. 29-32: Photomicrographs of histological sections of male gonad of N. teretiuscula; 29 Uninfected male follicles (MF) within connective tissue (CT); 10×. 30-32 Infected male gonads showing male follicles (MF) with cyst (C) of $R$. campanula, separated with connective tissues (CT) surrounded by few hemocytes (HC); 100×. 33-35 Photomicrographs of histological sections of female gonad of N. teretiuscula showing: 33 Uninfected female gonads with follicles (FF) and separated by connective tissues (CT); 100x. 34 Infected female gonads with sporocysts of $R$. campanula (C) surrounded by numerous hemocytes (HC) and connective tissue (CT); 100×. 35 Uninfected digestive gland; $100 \times$. 36, 37 Uninfected mantle showing the covering layer of epidermis (E), muscle fibre (MF), and connective tissue (CT); 400×.

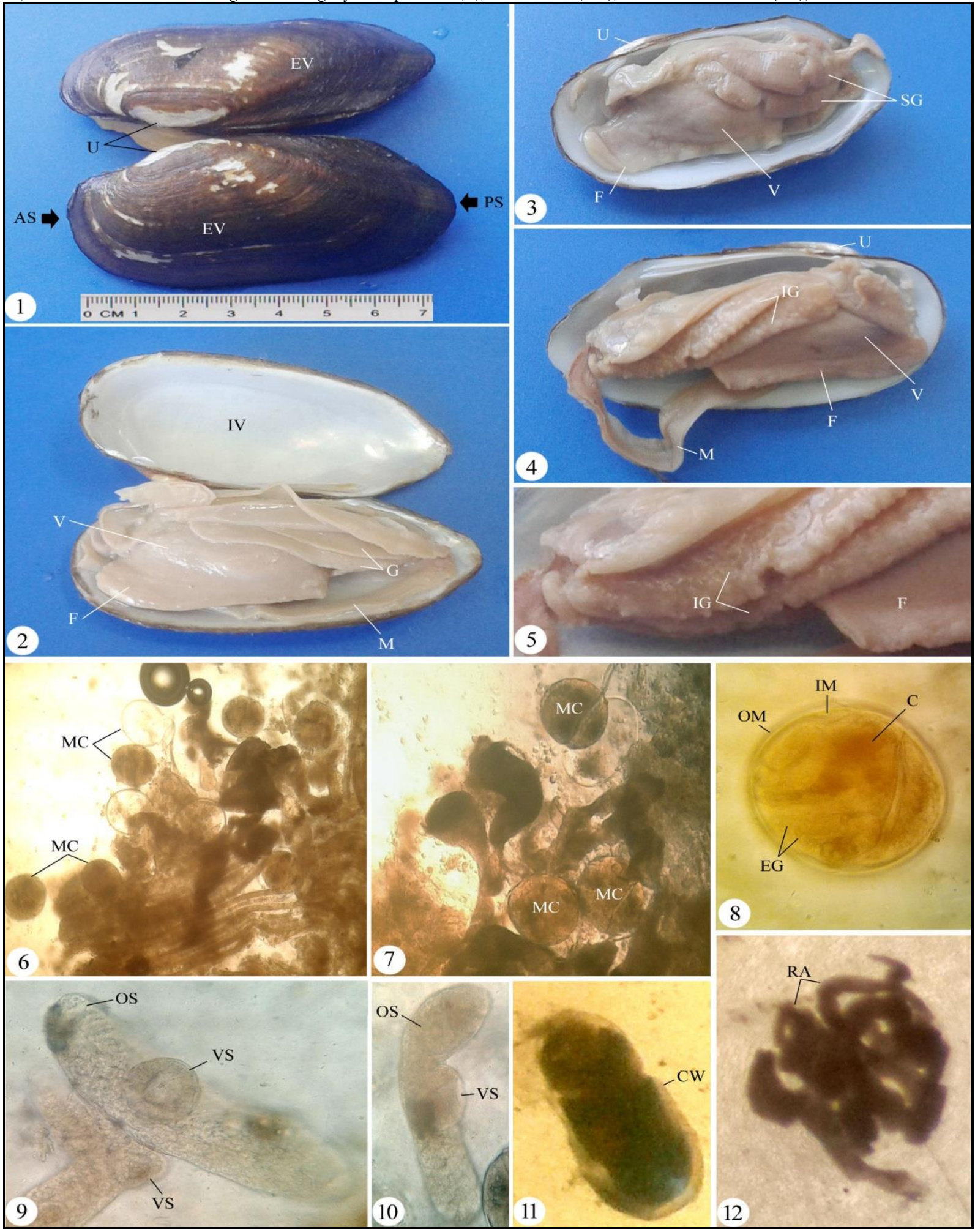



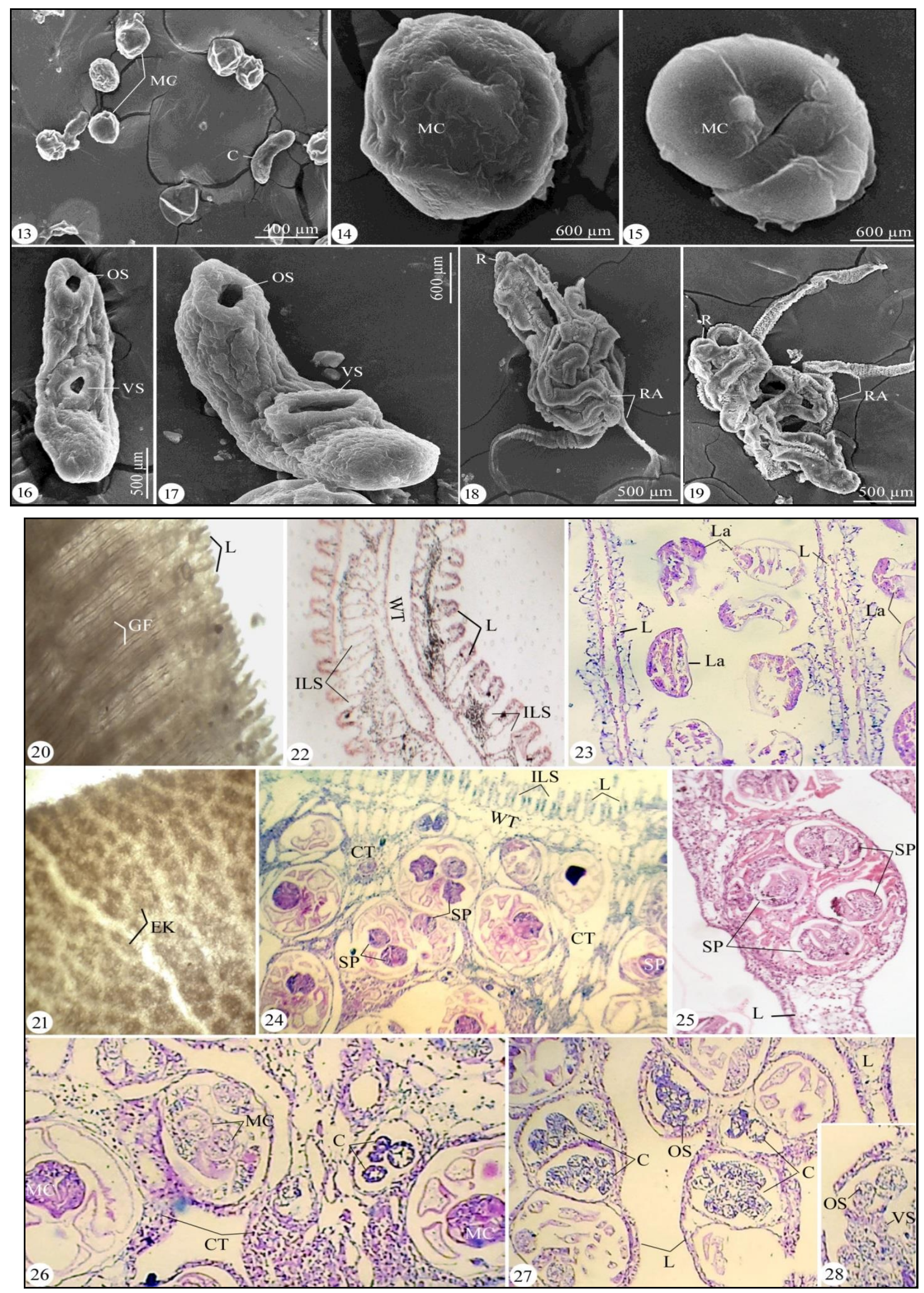


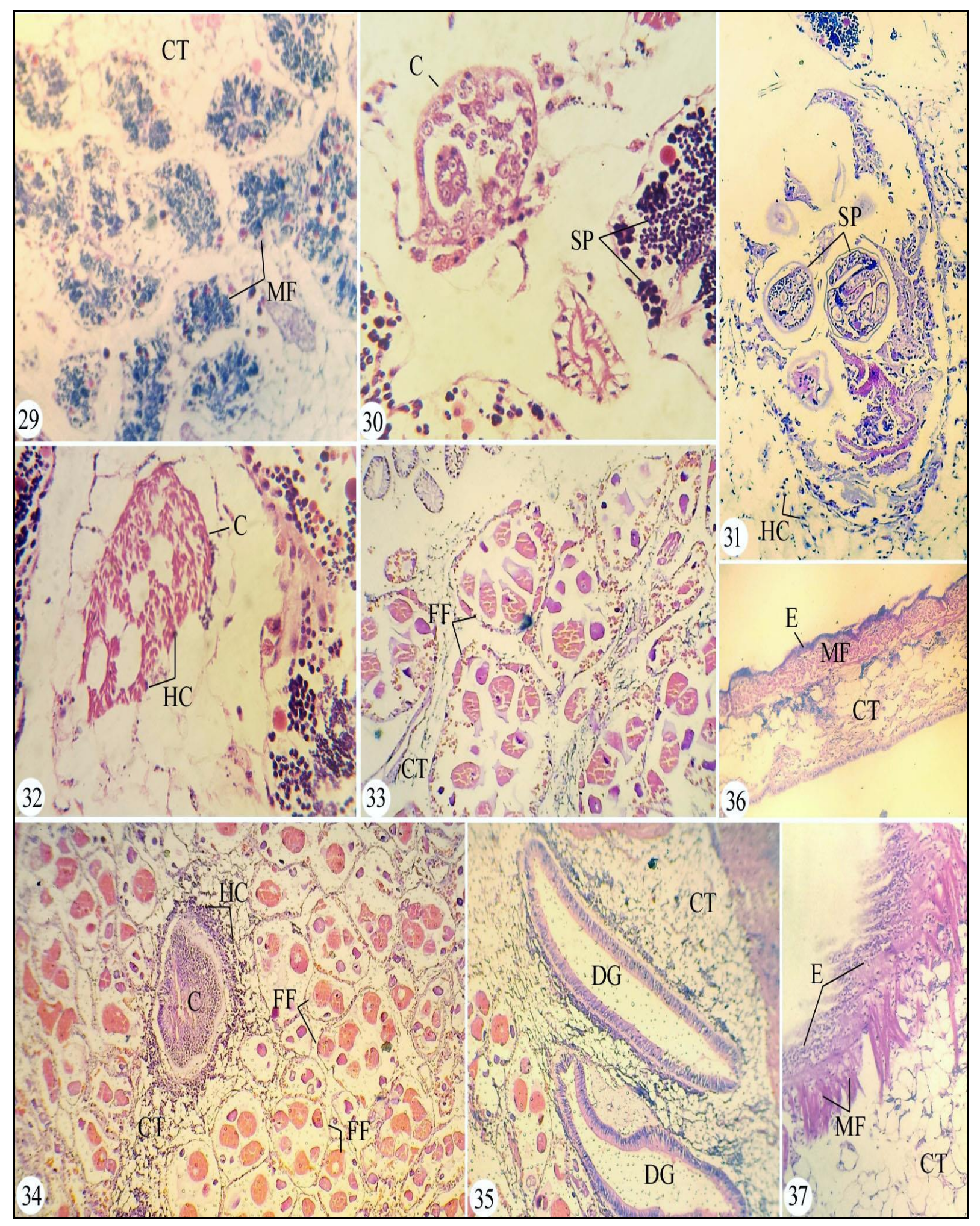




\section{EXPERIMENTAL EVALUATION OF THE ROLE OF SYMBIOTIC AND APOSYMBIOTIC, CULEX PIPIENS MOSQUITOES IN THE TRANSMISSION OF HEPATITIS C VIRUS (HCV)}

\section{By}

MOSTAFA I. HASSAN ${ }^{1}$, ALY F. MOHAMMED ${ }^{2}$, KOTB M. HAMMAD', A. GABARTY ${ }^{3}$, AND THARWAT A. SELIM ${ }^{1}$

Department of Zoology ${ }^{1}$, Faculty of Science, Al-Azhar University, Nasr City, Cairo, and VACSERA ${ }^{2}$, Giza, and Department of Natural Products ${ }^{3}$, National Center for

Radiation Research and Technology, Atomic Energy Authority, Cairo, Egypt.

$\left({ }^{\star}\right.$ Correspondence: E-mail:mostafa012@gmail.com)

\section{Abstract}

The present study evaluated the potential role of Culex pipiens mosquitoes in the transmission of HCV, post being fed on an infected blood with a viral load of $1.3 \times 10^{6} \mathrm{IU} / \mathrm{ml}$.in symbiotic mosquitoes and $1.2 \times 10^{6} \mathrm{IU} / \mathrm{ml}$.in aposymbiotic one. Mouth parts, mid-gut and salivary glands in both symbiotic and aposymbiotic mosquitoes at different time intervals were tested for evaluation of viral load using real-time PCR for up to 60min and up to 5, 13 day in case of mouth parts, mid-gut and salivary glands respectively. It was observed that the viral load was decreased by increasing the time post feeding in mid-gut and mouth parts in both symbiotic and aposymbiotic mosquitoes so, there is a negative relationship between the HCV load and feeding time. On the other hand, HCV was not detected in salivary glands in both symbiotic and aposymbiotic mosquitoes during the period of detection. The results showed that the mechanical transmission through mouth parts in both symbiotic and aposymbiotic mosquitoes are plausible, while biological transmission through symbiotic and aposymbiotic mosquitoes did not occur.

Key words: Culex pipiens, Symbiotic, Aposymbiotic, HCV, Transmission.

\section{Introduction}

The mosquitoes are vectors of many vertebrate blood parasites. In Egypt Culex pipens has a wide distribution and is the main vector of Rift Valley Fever (RVF) virus (Megan et al, 1980; Darwish and Hoogastraal, 1981; El Bahnasawy et al, 2013a), Wuchereria bancrofti (Khalil et al, 1930; Gad et al, 1996; Abdel-Hamid et al, 2013) and Western Nile Virus (Pelah et al, 2002; El Bahnasawy et al, 2013b). Hassan et al. (2003); Pybus et al. (2007); Tarish et al. (2014) and El Kholy et al. (2017) studied the possibility of the HCV experimental transmission by different mosquitoes.

Hepatitis C Virus infection is one of the major public health problems in both developed and developing countries since discovering at 1989 (Choo et al, 1989; Alter et al, 1989). It was estimated that $\mathrm{HCV}$ infect 200 million peoples $(3 \%)$ of the world's population and there are at least 21.3 million HCV carriers in the Eastern Mediterranean countries (Sy and Jamal,
2006). The infection acquired mainly via parenteral route (Karaca et al, 2006), and also perinatally (Indolfi and Resti, 2009), but there is $(30-40 \%)$ of infected cases were without identifiable route (Hayashi and Furusyo, 2010).

Many investigators suggested that the mechanical transmission of HCV by mosquitoes was plausible (Germi et al, 2001; Hassan et al, 2003; Pybus et al, 2007). This was in accordance to Kamal (2008) who reported that one viral particle was perhaps sufficient to induce infection via parenteral route. El Kholy et al. (2017) reported that the mosquito $C x$. pipiens may be a potential vector of HCV. However, the biological and mechanical of $\mathrm{HCV}$ transmission by mosquitoes showed negative results. Low HCV RNA titers in patient sera and different species tropisms for $\mathrm{HCV} / \mathrm{RNA}$ replication are probably the reasons why the mechanical and biological HCV transmission did not occur in mosquitoes (Chang et al, 2001). 